DOI:

\title{
PENDAMPINGAN PERBAIKAN PROSES PENGERINGAN PRODUK KERUPUK PADA UKM KARYA LESTARI DUSUN GUMAWANG PATUK KABUPATEN GUNUNGKIDUL
}

\author{
Okka Adiyanto $^{1}$, Muhammad Faishal ${ }^{2}$ \\ Universitas Ahmad dahlan, Jalan Prof. Dr. Soepomo, Janturan Yogyakarta 55164 1,2 \\ Email: Okka.adiyanto@ie.uad.ac.id
}

\begin{abstract}
ABSTRAK
Kerupuk merupakan salah satu makanan ringan yang sangat digemari oleh masyarakat Indonesia dan sering dijadikan sebagai pelengkap berbagai sajian makanan atau sebagai lauk pauk. Sehingga dapat dikatakan kerupuk merupakan makanan ringan yang tidak bisa lepas dari kehidupan masyarakat. Dusun Gumawang merupakan salah satu dusun yang terletak di Kabupaten Gunung Kidul. Dusun Gumawang memilik beberapa produk unggulan yang dapat dikembangkan salah satunya adalah kerupuk. Kerupuk yang diproduksi oleh Usaha peningkatan pendapatan keluarga sejahtera (UPPKS) Karya Lestari yaitu kerupuk legendar, kerupuk melinjo, dan sejenisnya. Dalam pengabdian di Dusun Gumawang ini tim menggunakan metode pemberdayaan masyarakat melalui pelatihan kepada masyarakat dan praktek langsung. Dalam pengabdian ini, salah satu kegiatan tim adalah memberikan alat bantu pengering yang membantu mempercepat proses pengeringan serta menjaga kualitas produk dari kontaminasi benda asing saat pengeringan di luar pada produk krupuk dari UPKKS Karya Lestari. Hasil pengabdian masyarakat ini dapat meningkatkan kualitas produk kerupuk.
\end{abstract}

Kata kunci : Pendampingan, pemberdayaan, kerupuk, pengering

\begin{abstract}
Crackers are one of the snacks that are very popular in Indonesia and are often used as a complement side dishes foods. So that it can be said crackers are snacks that cannot be separated from people's lives. Gumawang is one of the located in Gunung Kidul Regency. Gumawang has several superior products that can be developed, one of which is crackers. Crackers which are produced by Usaha peningkatan pendapatan keluarga sejahtera (UPPKS) Karya Lestari, namely crackers, legendar, melinjo crackers, and etc. In this service in Gumawang, the team used the method of community empowerment through training to the community and direct practice. In this service, one of the team's activities is to provide a drying machine that helps speed up the drying process and maintain product quality from foreign matter contamination while drying outside of the cracker product from UPKKS Karya Lestari. The results of community service can improve the quality of cracker products.
\end{abstract}

Keywords :: Mentoring, empowerment, crackers, dryer

\section{PENDAHULUAN}

Dusun Gumawang menjadi salah satu desa wisata yang ada di Kabupaten Gunung Kidul memiliki beberapa produk yang dapat dikembangkan, salah satu yang dikembangkan di wilayah tersebut yaitu produksi kerupuk. Kerupuk yang diproduksi oleh Usaha peningkatan 
pendapatan keluarga sejahtera (UPPKS) Karya Lestari yaitu kerupuk nasi, kerupuk melinjo, dan sejenisnya.

Dalam proses produksinya ada beberapa kelemahan pada produk kerupuk desa tersebut salah satunya lamanya proses pengeringan sebelum mengalami proses pengemasan. Selain itu juga sering rusaknya produk saat pengeringan dibawah sinar matahari akibat binatang liar dan kontaminasi benda asing. Kegiatan pembuatan kerupuk rambak ini bukan sekedar dijadikan usaha sampingan tetapi dapt untuk mencukupi kebutuhan sehari-hari (Yunita, 2009).

Permasalahan yang muncul di lokasi UKM salah satunya berhubungan dengan pengeringan kerupuk yang masih konvensional dapat dilihat pada Gambar 1

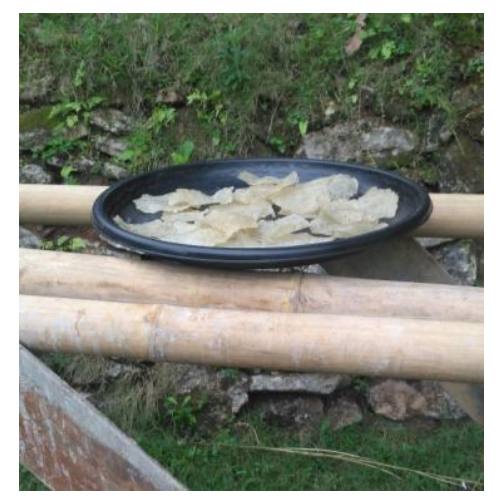

Gambar 1 Pengeringan secara konvensional

Kerugian dari pengeringan kerupuk secara konvensional yaitu dapat dilihat dari segi kebersihan. Selama ini pengeringan kerupuk yang dilakukan oleh industri kecil masih dilakukan ditempat terbuka, sehingga tidak terjamin kebersihannya dan kurang hygienis untuk dikonsumsi. Mengatasi semua permasalahan tersebut diatas, maka dibutuhkan alat pengering yang dapat digunakan untuk menjaga kestabilan proses produksi baik dimusim panas maupun musim penghujan. Salah satu bentuk pengering yang cocok untuk diterapkan dalam proses pengeringan pada kerupuk legendar yaitu pengering tipe rak (Adiyanto, Suratmo, \& Susanti, 2017).

Pemahaman tentang produksi dari mitra masih sebatas pengetahuan pada umumnya sehingga perlu diupayakan pengajuan program pelatihan dalam pengelolaan usaha secara komprehensif, yaitu sejak dari penyiapan sarana dan prasarana hingga penanganan produk. Diharapakan dengan adanya pelatihan tersebut para pengelola dapat mengoptimalkan kemampuannya. Adapun untuk aspek produksi terhadap produk olahan terdapat beberapa keterbatasan, diantaranya pemahaman tentang manajemen produksi, minimnya sarana dan prasarana produksi untuk hasil olahan produk kerupuk beras (legendar). 
Manajemen usaha diperlukan sebagai landasan dan pengetahuan untuk mengawali adanya unit usaha yang akan dibentuk (home industry). Unit usaha ini berada dibawah UPKKS Karya Lestari Dusun Gumawang Kecamatan Patuk Kabupaten Gunung Kidul. UPKKS ini merupakan salah satu Dusun Binaan yang dikelola oleh Program Studi Teknik Industri Universitas Ahmad Dahlan. UPKKS ini juga telah memiliki PIRT.

Dari permasalahan yang ada, pengabdian masyarakat ini bertujuan untuk menberikan pendampingan pada kelompok usaha pembuatan kerupuk legendar agar dapat memeperbaiki proses proses produksinya khususnya tahap pengeringan sehingga mampu meningkatkan produktifitas dan kualitas produk kerupuk legendar.

\section{METODE}

Metode yang digunakan untuk mencapai tujuan yang diharapkan, program pemberdayaan masyarakat di Dusun Gumawang dilakukan dengan pemberdayaan masyarakat melalui pendidikan masyarakat dan praktek langsung. Ringkasan metode pelaksanaan beserta jam kerja tersaji pada table I.

Table 1 Metode, Kegiatan,jam kerja

\begin{tabular}{|l|l|l|l|}
\hline No & Metode & Kegiatan & Jam Kerja \\
\hline 1 & $\begin{array}{l}\text { Pendidikan } \\
\text { masyarakat }\end{array}$ & $\begin{array}{l}\text { Pelatihan dan pendampingan pembuatan produk kerupuk yang } \\
\text { variatif dan pengemasan yang menarik }\end{array}$ & $2 \times 3$ jam \\
\hline 2 & $\begin{array}{l}\text { Pembuatan } \\
\text { alat }\end{array}$ & $\begin{array}{l}\text { Pembuatan alat bantu pengering ini dilakukan di Laboratorium } \\
\text { Pengelasan Teknik Industri Universitas Ahmad Dahlan } \\
\text { Yogyakarta }\end{array}$ & 3 Minggu \\
\hline 3 & \multirow{2}{*}{ Praktek } & Pembuatan alat bantu pengering & $2 \times 3$ jam \\
\cline { 3 - 4 } & Pemberian alat pengering kerupuk & $1 \times 2$ jam \\
\cline { 3 - 5 } & Sosialisasi penggunaan alat pengering kerupuk & 2 jam \\
\hline
\end{tabular}

\section{HASIL, PEMBAHASAN, DAN DAMPAK}

Setiap daerah di Indonesia rata-rata memiliki produk olahan kerupuk. Masing masing daerah memiliki ciri khas produk olahan yang dihasilkannya. Kerupuk merupakan suatu jenis makanan kecil yang sudah lama dikenal oleh sebagian besar masyarakat 
Indonesia. Kerupuk dapat dikonsumsi sebagai makanan selingan maupun sebagai variasi dalam lauk pauk (Koswara, 2009). Banyaknya jenis kerupuk maka perlu memunculkan ke khasan dari olahan kerupuk yang diproduksi di Dusun Gumawang. Maka diperlukan suatu penyuluhan maupun pendampingan untuk pembuatan produk kerupuk yang variatif. Oleh karena itu program pengabdian masyarakat PPM UAD memberikan penyuluhan dan pendampingan terhadap UPKKS Karya Lestari. Materi diisi oleh Muhammad Faishal, S.T., M.Eng selaku dosen Teknik Industri Universitas Ahmad dahlan. Pada pelatihan dan pendampingan ini diisi dengan kegiatan berupa pelatihan beberapa cara membuat kerupuk yang ada di Indonesia melalui tayangan video. Selanjutnya dilakukan pelatihan pengemasan produk yang baik oleh Okka Adiyanto, STP, M.Sc dosen Teknik Industri UAD. Di mana pada pelatihan tersebut ditunjukkan beberapa contoh pengemasan produk yang menarik dan mampu menjaga kualitas produk.

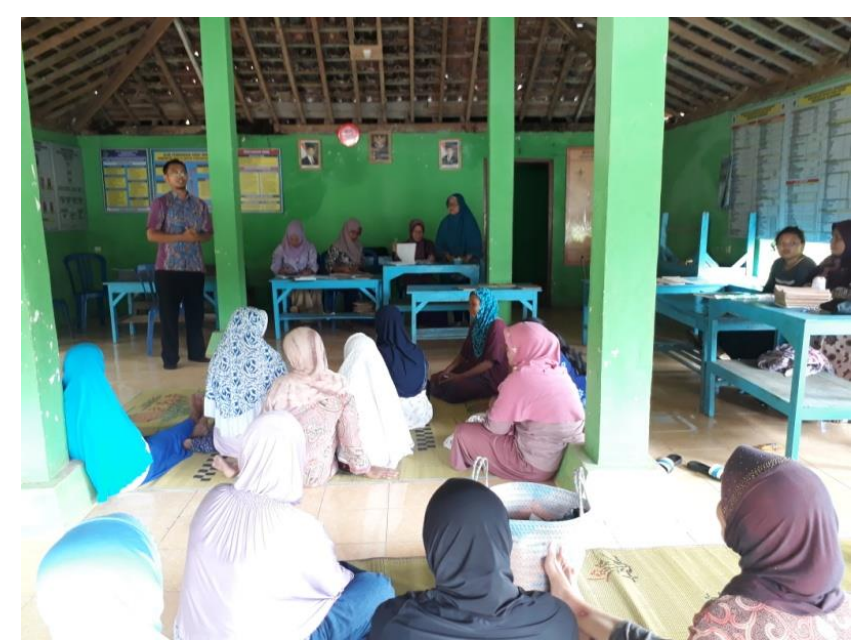

Gambar 1. Pelatihan pembuatan produk kerupuk yang variatif dan pengemasan yang menarik

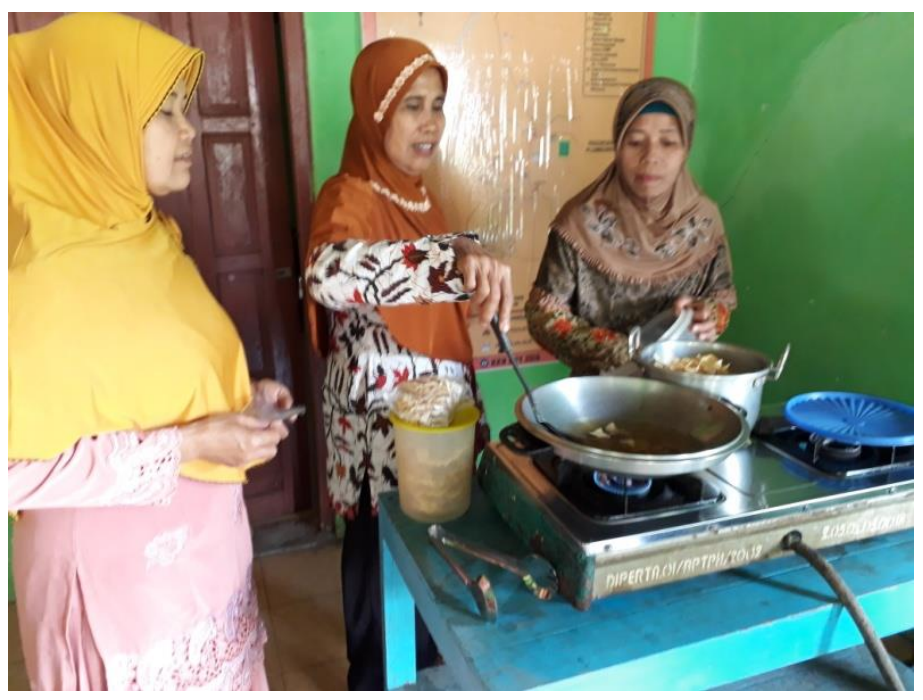

Gambar 4. Pelatihan pembuatan kerupuk 
Proses pembuatan alat bantu pengering ini dilakukan di Laboratorium Pengelasan Teknik Industri Universitas Ahmad Dahlan Yogyakarta. Dalam pembuatan alat bantu pengering ini Tim pengabdian masyarakat dibantu oleh laboran Teknik Industri dan juga mahasiswa asisten praktikum proses manufaktur. Pembuatan alat bantu pengering ini dilakukan sekitar 3 minggu pengerjaan.

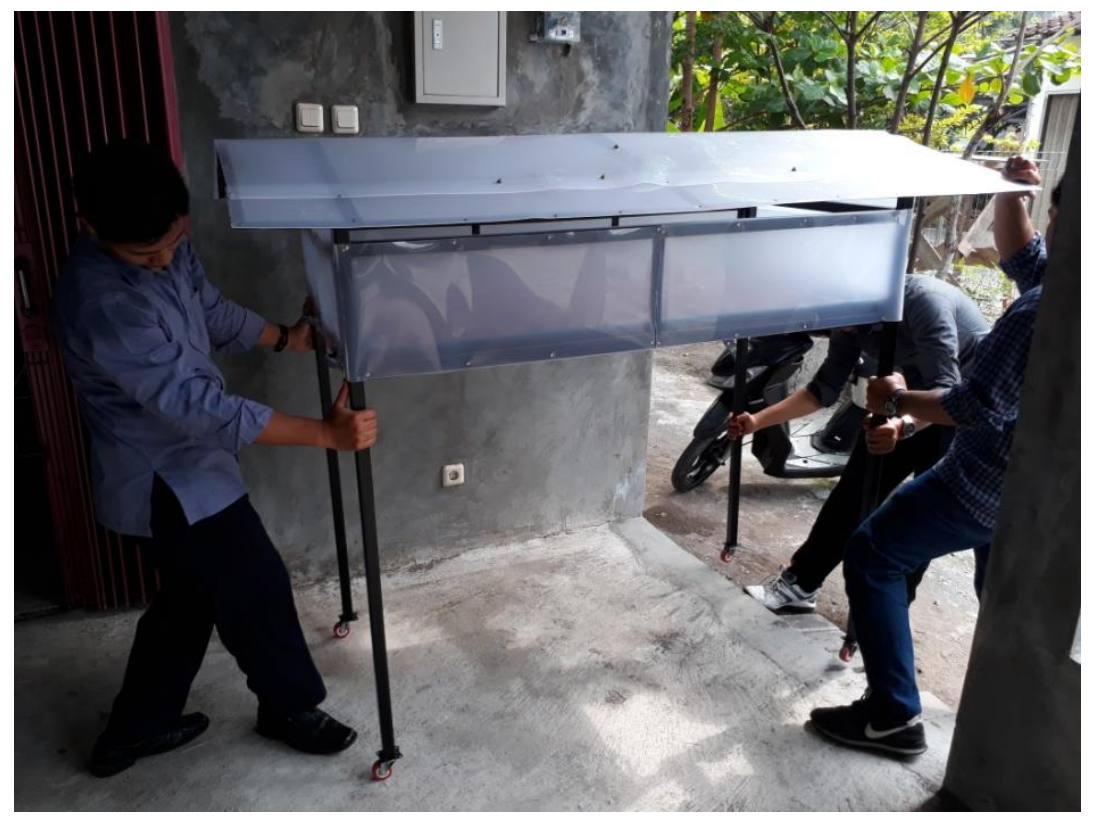

Gambar 5 Pembuatan alat pengering

Acara ini sudah terlaksana pada tanggal 8 Juni 2018, acara ini yaitu memberikan alat bantu pengering kepada perwakilan UPPKS Karya Lestari. Selanjutnya tim menjelaskan tentang cara kerja alat pengering tersebut dan mempraktekkan langsung penggunaan alat pengering tersebut.

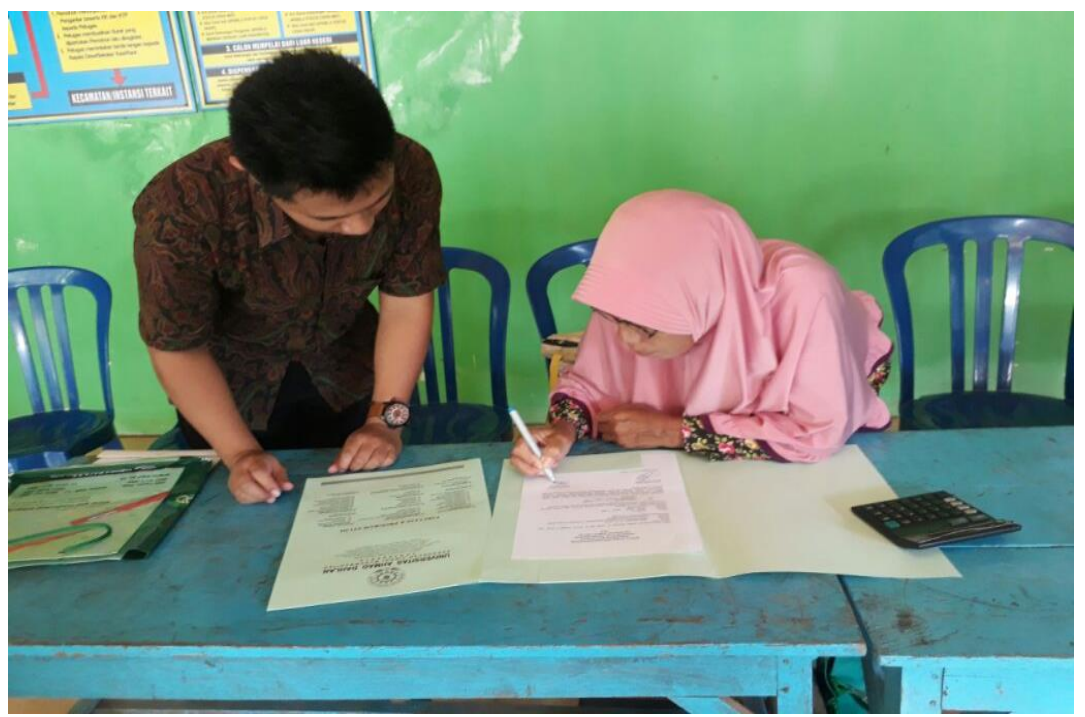

Gambar 7. Serah Terima bantuan alat kepada perwakilan UPPKS Karya Lestari 


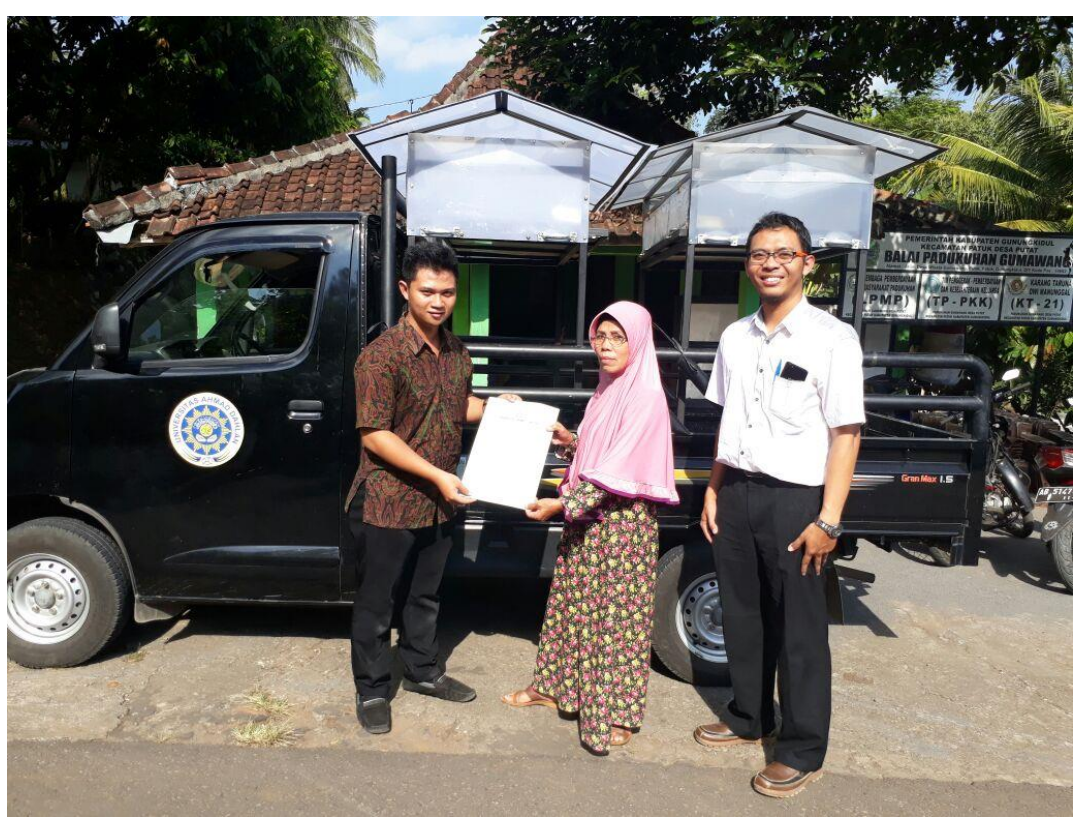

Gambar 8. Alat pengering yang diberikan

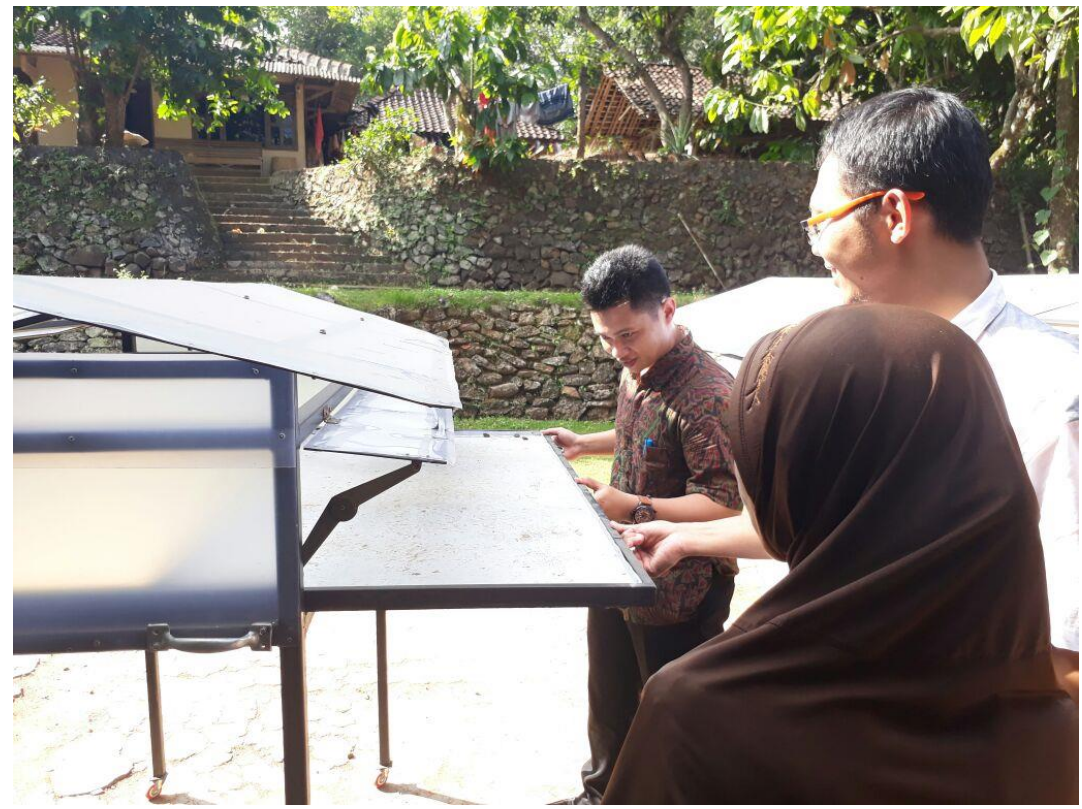

Gambar 9. Tutorial penggunaan alat bantu pengering

\section{SIMPULAN}

Kesimpulan dari pengabdian masyarakat yang berjudul Pendampingan Perbaikan Proses Pengeringan Produk Kerupuk Pada UKM Karya Lestari Dusun Gumawang Patuk Kabupaten Gunungkidul dapat meningkatkan produksi kerupuk adalah adanya peningkatan produksi. Peningkatan produksi ini diakibatkan oleh terbantunya proses pengeringan yang dilakukan menggunakan bantuan alat bantu pengering. Diperlukan 
kontinuitas pengabdian terhadap masyarakat Gumawang sehingga apa yang sudah diberikan dapat selalu bermanfaat.

\section{DAFTAR PUSTAKA}

Adiyanto, O., Suratmo, B., \& Susanti, D. Y. (2017). Perancangan Pengering Kerupuk Rambak Dengan Menggunakan Kombinasi Energi Surya Dan Energi Biomassa Kayu Bakar. JISI: Jurnal Integrasi Sistem Industri, 4(1), 1-10.

Yunita, T, (2009). Analisa Kelayakan Finansial Industri Kerupuk Rambak yang aman dikonsumsi. Skripsi FTP UGM. Yogyakarta.

Koswara, Sutrisno (2009). Pengolahan Aneka Kerupuk. Ebookpangan.com

\section{UCAPAN TERIMAKASIH}

Terima Kasih kepada LPPM Universitas Ahmad Dahlan yang telah membiayai pengabdian masyarakat ini sehingga dapat terlaksana dengan baik. 
